\title{
Molecular Breeding of a Yeast that Produces Human Compatible Glycoproteins
}

\author{
ヒト適応型糖タンパク質を生産する出芽酵母の分子育種
}

\author{
Nakayama, Ken-ichi ; Chiba, Yasunori ; and Jigami,Yoshifumi \\ Institute of Molecular and Cell Biology, National Institute of Advanced Industrial Science and Technology \\ Tsukuba Central 6, 1-1 Higashi, Tsukuba 305-8566, Japan \\ FAX:81 298-61-6220, E-mail: k-nakayama@aist.go.jp
}

Key Words : glycoprotein, molecular breeding, oligosaccharide, yeast

\begin{abstract}
s
The yeast Saccharomyces cerevisiae is a eucaryote that is easy to use for gene engineering and in cultivation. Yeast is suitable for production of valuable secretory proteins; however, in the case of production of glycoproteins in yeast, the mannose outer chain that consists of 30-100 mannose residues is attached to the $N$-linked oligosaccharide of the glycoproteins, which causes problems such as immunogenecity against humans or a reduction in protein activity. We have studied the molecular breeding of a yeast that produces human compatible glycoproteins by eliminating the yeast mannose outer chain and adding of essential genes for the synthesis of mammalian type oligosaccharide. In this study, we successfully cloned and disrupted the $\mathrm{OCH} 1$ gene that encodes essential mannosyltransferase for the synthesis of mannose outer chain. We also succeeded in the cloning and disrupting the MNN4 and MNN6 genes that are involved in yeast specific mannosylphosphorylation. Furthermore we tried to clone glycosyltransferases, glycosidases, and sugar nucleotide transporter genes for the synthesis of mammalian type sugar chain, and tried to express these genes in yeast. In this report we introduce the results of these studies.
\end{abstract}

\section{A. Introduction}

The yeast Saccharomyces cerevisiae is easy to use for gene engineering and in cultivation. Moreover, yeast is a eucaryote whose secretion system is almost the same as that of mammalian cells in areas such as protein sorting and holding mechanisms. For that reason, yeast is suitable for the production of human proteins, especially secretory proteins. However, in the case of glycoprotein production, the poly-mannose outer chain that consists of 30-100 mannose residues is attached to the $N$-linked oligosaccharide chain of glycoprotein (1) (Fig.1), which causes problems such as immunogenecity against humans or a reduction in the protein activity. The $N$-linked glycosylation pathways are identical in yeast and mammalian cells up to the oligosaccharide assembly on dolichol pyrophosphate (Dol-PP) in the endoplasmic reticulum (ER) (2). This fact indicated that
要 約

出芽酵母 Saccharomyces cerevisiae は、遺伝子操作や培養が 容易な真核生物であり、有用タンパク質などの分泌発現系とし ては優れたものである。しかしながら、糖タンパク質の生産に 扔いては、マンノース $30-100$ 残基という大きな糖外鎖が $N$ - 結 合型糖鎖に結合することから、ヒトに対する抗原性の付与や夕 ンパク質の活性低下などの問題を引き起こしている。我々は、 この酵母の $N$ - 結合型糖外鎖の除去及び哺乳類型糖鎖合成に必要 な遺伝子の酵母への導入を行い、ヒトに適合できる糖タンパク 質を生産可能な酵母の分子育種を行ってきた。この研究におい て、我々は、醅母の大きな糖外鎖を形成するのに必要なマン ノース転移酵素をコードする $O C H 1$ 遺伝子の単離と破壊に成功す ると共に、同じく酵母特有のマンノースリン酸転移に関わる遺 伝子MNN4とMNN6の単離と破壊に成功した。このことにより、 ほぼ完全に酵母特有の糖外鎖の形成を取り除くことに成功し た。さらに、哺乳類型糖鎖の、混成型や複合型糖鎖を酵母で合 成可能とするために、様々な糖転移酵素、糖分解酵素、糖又ク レオチド輸送体などの遺伝子の単離と酵母での発現を試みてき た。その成果をここに紹介する。

\section{A. 序}

出芽酵母 Saccharomyces cerevisiae は遺伝子操作が容易であ り、培養が簡単な微生物である。しかも真核生物であり、タン パク質の分泌過程、そのホールディングや成熟過程に関して は、ほぼ動物細胞と同じであることから、ヒトなどのタンパク 質の生産に適していると考えられる。しかしながら、糖タンパ ク質の生産の場合、30から100残基のマンノースから成る $N$ - 結 合型糖鎖が付加してしまい(1)(図1)、抗原性の付与やタンパク質 の活性低下などを引き起こす。この $N$ - 結合型糖鎖の生合成は小 胞体(ER)でのドリコールリン酸上での糖鎖合成までは酵母と動 物細胞でほほ同じである(2)。これは、酵母と動物細胞の $N$-結合 型糖鎖の違いは、ゴルジでの糖鎖付加が異なるためであること 


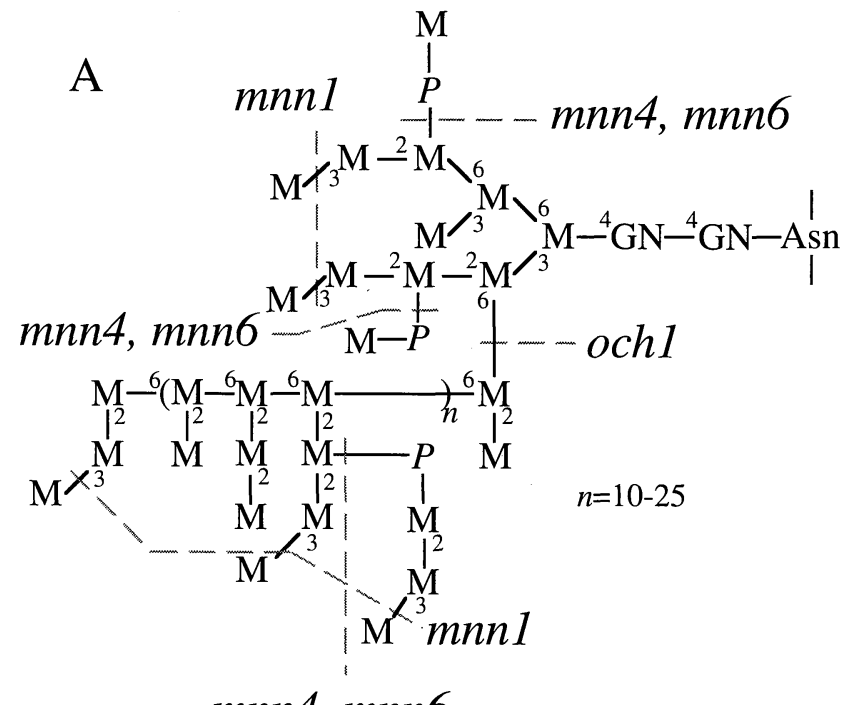

the difference of $N$-linked oligosaccharide structure in yeast and mammalian cells was derived from the glycosylation system in Golgi. Therefore, we thought that it would be possible to breed yeast cells that produce a human compatible glycoprotein by changing the glycosylation system in Golgi from a yeast type system to a mammalian type system. For changing the glycosylation system in Golgi, we studied yeast specific glycosylation genes in Golgi and disruption of these genes, and introduction of mammalian specific glycosylation genes in Golgi to yeast cells.

As a result of these studies, we had found the $\mathrm{OCHI}$ gene, which encodes initiation specific $\alpha-1,6$-mannosyltransferase for synthesis of the yeast poly-mannose outer chain in $N$-linked oligosaccharides $(3,4) . M N N 4$ and $M N N 6$ genes had also been found as the positive regulator and transferase gene of a mannosylphosphorylation individual $(5,6)$, which is also a yeast specific oligosaccharide residue. By the disruption of these $O C H 1, M N N 4$ and $M N N 1$, that encode yeast specific terminal $\alpha$-1,3-mannosyltransferase (7), we successfully bred the yeast that attaches a kind of mammalian high mannose type oligosaccharide ( $\mathrm{Man}_{8} \mathrm{GlcNAc}_{2}$ ) to glycoproteins (Fig.1). Furthermore, this bred yeast was converted to the yeast that attaches $\mathrm{Man}_{5} \mathrm{GlcNAc}_{2}$ oligosaccharide by introduction of the mannosidase I gene that encodes $\alpha$-1,2-mannosidase. In this paper, we describe how to clone the yeast specific glycosylation genes and breed the yeast that produces the human compatible glycoprotein.

\section{B. Cloning of $\mathrm{OCH} 1 \mathrm{Gene}(3,4,8)$}

The ochl mutant, which had been isolated by Nagasu et
B

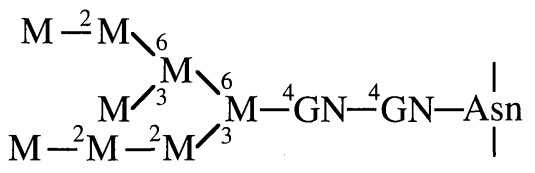

Fig. 1. $N$-linked oligosaccharides of wild type yeast and molecular breeding yeast. The mutation genes that affect yeast specific glycosylation are shown by italic. By the disruption of these yeast specific glycosylation genes, yeast type oligosaccharide (A) is converted to human compatible high mannose type $\left(\mathrm{Man}_{8} \mathrm{GlcNAc}_{2}\right.$ ) oligosaccharide (B). M, mannose; GN, $N$ acetylglucosamine; P, phosphate.
を示している。このことから、 $N$ - 結合型に関しては酵母のゴル ジでの糖鎖修飾を動物細胞型に代えることによって、ヒト適合 型糖鎖を生産する酵母の育種が可能ではないかと考えられた。 そこで我々は、酵母特有のゴルジでの糖鎖修飾を破壊する、動 物細胞のゴルジでの糖鎖修飾に必要な遺伝子を酵母に導入す る、という2つの研究を始めた。

これまでの研究の結果、我々は、酵母のポリマンノース外

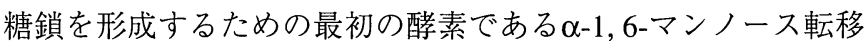
酵素をコードする $O C H 1$ 遺伝子を見出した $(3,4)$ 。さらに、酵母 に特異的な糖鎖残基であるマンノースリン酸の付加に関与する MNN4およびMNN6をそれぞれ正の制御因子と転移䤉素遺伝子と して見出した $(5,6)$ ここれらの $O C H 1$ 遺伝子、MNN4遺伝子、さら に酵母特有の $\alpha-1,3$-マンノース転移酵素遺伝子である $M N N I(7)$ を全て破壊することで、動物細胞の高マンノース型糖鎖の一つ である $\mathrm{Man}_{8} \mathrm{GlcNAc}_{2}$ を糖タンパク質に付加をする酵母の育種に 成功した(図1)。さらに、この酵母に $\alpha-1,2$-マンノース分解酵素 をコードする，マンノシダーゼI 遺伝子を導入することによっ て $\mathrm{Man}_{5} \mathrm{GlcNAc}_{2}$ の高マンノース型糖鎖まで削り込むことに成功 している。今回、この酵母特異的な糖鎖修飾遺伝子の取得した 過程と、ビト適合型糖タンパク質を生産する酵母の分子育種に ついて紹介する。

B. $O C H I$ 遺伝子のクローニング $(3,4,8)$

長洲らによって取得されたochl変異株は、ポリマンノース 
al., shows a deficiency in poly-mannose outer chain elongation in the yeast $S$. cerevisiae (9). We have cloned the $O C H 1$ gene by complementation of its temperature sensitive (ts) phenotype for growth. The SalI-HindIII $2.6 \mathrm{kbp}$ fragment was found to complement the ts phenotype. The unique open reading frame (ORF) of 1,443 bp was found within the SalI-HindIII fragment of $\mathrm{OCHl}$ gene. This ORF encodes a protein of 480 amino acids with a molecular weight of $55,155 \mathrm{Da}$. A hydropathy profile of the predicted Ochlp indicated a membrane spanning protein with a single hydrophobic region near the $\mathrm{NH}_{2}$-terminus and a hydrophilic region at the $\mathrm{COOH}$-terminal side. Four potential $\mathrm{N}$-linked glycosylation sites (Asn-X-Ser/Thr) were found in the large $\mathrm{COOH}$-terminal region. In vitro translation and translocation of Ochlp was performed by using the rabbit reticulocyte lysate and canine pancreatic microsomal membranes. While the translation product in the absence of membranes showed the $55 \mathrm{kDa}$ band, which is identical to the predicted molecular weight of Och1p, four discrete bands larger than $55 \mathrm{kDa}$ were observed in the presence of membranes. These larger bands were protected from proteinase $\mathrm{K}$ digestion, indicating that the large $\mathrm{COOH}$-terminal region of Och $1 \mathrm{p}$ was located in the lumenal side. When these lager bands were treated with endoglycosidase $\mathrm{H}$ (Endo $\mathrm{H}$ ), a $55 \mathrm{kDa}$ band was observed, confirming that the Ochlp is a glycoprotein containing four $N$-linked sugar chains (3).

The localization and properties of Och1p were analyzed in yeast cells by using the anti-peptide antibody. The yeast cells that express the Ochlp was lysed and separated into cytosolic and membrane fractions. The Och $1 \mathrm{p}$ bands were observed in the ER rich membranes and Golgi rich membranes fractions, while no specific bands were observed in the cytoplasmic fraction. The above data suggest that the Och1p is a membrane protein that resides in the ER and/or Golgi membranes in vivo. The Ochlp bands were shifted to low molecular weight by Endo $\mathrm{H}$ digestion. The $N$-linked oligosaccharide length of the Ochlp expressed in yeast was almost the same or slightly larger than the $\mathrm{Man}_{8} \mathrm{GlcNAc}_{2}$ formed in the ER because the estimated molecular weight of $N$-glycosylated Och1p by in vitro translation/ translocation was almost identical with the molecular weight of Och $1 p$ in yeast. This result also suggests that the Och1p may exist in the ER and/or early Golgi membranes (3).

The mannosyltransferase activity of Och $1 \mathrm{p}$ was measured by using various sugar chains or glycoprotein as an acceptor. We found that only the mannoprotein prepared from ochl gene disruptant was recognized as an acceptor by Ochlp. According to the results that $\mathrm{Man}_{8} \mathrm{GlcNAcOH}$ did not serve as an acceptor for Och1p and that the length of $N$-linked sugar chain of ochl mutant seemed to be larger than $\mathrm{Man}_{8} \mathrm{GlcNAc}_{2}$, we first thought that Och $1 \mathrm{p}$ as an elongation specific mannosyltransferase for synthesis of yeast poly-mannose glycochain (3). However, analysis of the oligosaccharide structure of ochl mutant and
糖外鎖の伸長の欠損を示した(9)。我々はOCHI遺伝子を温度感受 性(ts)の相補性により単離を行った。Sall-HindIIIの2.6 kbpの断片 がtsの形質の相補性を示した。このOCHI遺伝子のSall-HindIII断 片中に1443 bpからなる唯一のORFを見出した。このORFには480 アミノ酸からなる分子量55,155のタンパク質がコードされる。 Ochlpの疎水性予測によると、 $\mathrm{NH}_{2}$-末端付近に膜貫通可能な疎水 性部分を持ち、 $\mathrm{COOH}$-末端部分は親水性であることが分かっ た。この大きな親水性 $\mathrm{COOH}$-末端親水性領域には、4カ所の $N$ 結合型糖鎖付加可能部位(Asn-X-Thr/Ser)が見出された。生体外 のウサギ網状赤血球ライセートと犬膵臓膜画分を用いたOch $1 \mathrm{p}$ の翻訳および膜透過実験を行った。犬膵臓膜画分を加えなかっ たものは翻訳産物として予測された分子量と同じ值である55 $\mathrm{kDa}$ のバンドを示したが、膜画分を加えたときには、4つの55 $\mathrm{kDa}$ 以上のバンドが検出された。この分子量の大きなバンドは プロテアーゼKによる分解に抵抗性を示したことから、Och1pの 大きな $\mathrm{COOH}$-末端部分は膜内腔側を向いていることが分かっ た。この分子量の大きなバンドをエンドグリコシダーゼH(Endo H)で切断したところ、55kDaのバンドに分子量が下がった。こ のことはOch1pに4つの $N$-結合型糖鎖が付加していることを示し ている(3)。

Och $1 \mathrm{p}$ の酵母内での局在と性質の解析を抗ペプチド抗体を 用いて行った。Och1pを発現している醅母を破砕し、細胞質画 分と膜画分に分離を行った。Och1pはERが主に含まれている膜 画分及びゴルジ体が主にふくまれている膜画分に検出され、細 胞質画分には検出されなかった。これらの結果は、Och1pは膜 タンパク質であり、ERもしくはゴルジに局在することを示して いる。このOch1pのバンドはEndo Hの処理により低分子側に移 動した。酵母で発現されたOch1pに結合する $N$-結合型糖鎖の長 さは、酵母で発現されているOch1pの分子量とin vitroのタンパ ク質合成・膜透過系で作られる Ochlpの糖鎖修飾されたものの 分子量がほぼ一致することから、ERで形成される $\mathrm{Man}_{8} \mathrm{GlcNAc}_{2}$ と同じかもしくは少し大きいと思われる。この結果も、Och1p が、ERもしくはゴルジ体のシス側に存在しているということを 支持している(3)。

Ochlpのマンノース転移酵素活性測定を種々の糖鎖や糖タン パク質を糖受容体として用いて行ったところ、ochl遺伝子破壊 株より単離したマンナンタンパク質以外は、Och1pは糖受容体と して認識しないことが見出された。このとき $\mathrm{Man}_{8} \mathrm{GlcNAcOH}$ Och 1 pに糖受容体として認識されなかったことから、また、 $o c h l$ 遺伝子破壊株の $N$-結合型糖鎖の長さが $\mathrm{Man}_{8} \mathrm{GlcNAc}_{2}$ より大 きいと思われたことから、当初我々は酵母のポリマンノース糖 外鎖を合成する際の伸長に働くマンノース転移酵素であると考 えた(3)。しかしながら、ochl変異株及び遺伝子破壊株の糖鎖構 造解析の結果、och1変異はポリマンノース外鎖合成の最初に働 
ochl gene disruptant showed that the ochl mutant was deficient in initiation specific mannosyltransferase for synthesis of the poly-mannose outer chain (4). Although the major peak of $N$-linked oligosaccharide in ochl mutant was $\mathrm{Man}_{9} \mathrm{GlcNAc}_{2}$, attached mannose was the terminal $\alpha-1,3$-linkage to $\mathrm{Man}_{8} \mathrm{GlcNAc}_{2}$, not the initiation specific $\alpha-1,6$-mannose for outer chain synthesis (4).

Further analysis of Och $1 \mathrm{p}$ specific activity indicated that Och $1 \mathrm{p}$ is initiation specific $\alpha$-1,6-mannosyltransferase that recognizes $\mathrm{Man}_{8} \mathrm{GlcNAc}_{2}$ and $\mathrm{Man}_{8}$ GlcNAc as an acceptor, but not $\mathrm{Man}_{8} \mathrm{GlcNAcOH}$. This result indicated that at least one pyranose form of GlcNAc residue attached to $\beta-1,4-$ linked mannose is essential for the recognition by Ochlp (8).

In conclusion, we found that the $\mathrm{OCH} 1$ gene encodes the initiation specific $\alpha-1,6$-mannosyltransferase for synthesis of yeast poly-mannose outer chain in $\mathrm{N}$-linked oligosaccharide. We also showed that the yeast specific poly-mannose outer chain was removed by the gene disruption of $\mathrm{OCH}$.

\section{Mannosylphosphorylation of Oligosaccharide in Yeast (10)}

Although the poly-mannose outer chain was removed by disruption of the $\mathrm{OCH} 1$ gene, mannosylphosphate residue was still present as a yeast specific oligosaccharide residue (11). Oligosaccharide phosphorylation occurs in mammalian cells as mannose-6-phosphate, as a sorting signal to lysosome $(12,13)$. However, in yeast, another mannose residue is attached to mammalian type mannose-6-phosphate and showed strong immunogenecity. The addition of mannosylphosphate residue results from the mannose-1-phosphate transfer from GDP-mannose in yeast, instead of the GlcNAc-1-phosphate transfer from UDP-GlcNAc in mammals. In mammalian cells, GlcNAc residue of GlcNAc-1-phosphate is removed, but mannose residue of mannose-1-phosphate is not removed in yeast cells. This mannosylphosphorylation occurs in $\mathrm{N}$ - and $O$-linked oligosaccharides $(11,14)$. A common part of $N$-linked oligosaccharide synthesized in ER $\left(\mathrm{Man}_{8} \mathrm{GlcNAc}_{2}\right)$ is also attached to this mannosylphosphate residue. Therefore this mannosylphosphate residue must be removed from oligosaccharide for the production of human compatible glycoprotein in yeast.

Fortunately, the mutations that are deficient in this mannosylphosphorylation have already been found, and they are mnn4 (15) and mnn6 (16). The mnn4 and mnn6 mutants show the negative staining phenotype by alcian blue dye. The $M N N 6$ gene was isolated by complementation of this alcian blue dye staining phenotype (6). The $M N N 6$ gene encodes a type II membrane protein that consists of 446 amino acids. The Mnn6p is identical with Ktr6p, which is a homologue of Kre2p. As the Kre2p was known as $\alpha-1,2$-mannosyltransferase, Mnn6p was thought to be a mannosylphosphate transferase itself. In fact, the membrane fraction prepared from the mnn6 gene
くマンノース転移酵素の変異であることが示された $(4) 。 o c h 1$ 変 異株の $N$ - 結合型糖鎖の主な糖鎖はMan ${ }_{9}$ GlcNAc 2 であったが、 付加されていたマンノースは末端の $\alpha-1,3$-マンノースであり、 糖外鎖合成のための最初に付加する $\alpha-1,6$-マンノースではなかっ た(4)。

さらなる Och $1 \mathrm{p}$ の基質特異性の解析の結果、Och $1 \mathrm{p}$ は $\mathrm{Man}_{8} \mathrm{GlcNAc}_{2}$ および $\mathrm{Man}_{8} \mathrm{GlcNAc}$ 糖受容体とする糖鎖伸張開始 の $\alpha-1,6$-マンノース転移醳素であるが、 $\mathrm{Man}_{8} \mathrm{GlcNAcOH}$ は糖受 容体として認識しないと言うことが明らかとなった。このこと は、Och1pの認識には少なくともマンノースに $\beta-1,4$-結合で付加 しているGlcNAcの1残基がピラノース型になっている必要がある ことを示している(8)。

以上をまとめると、OCH1遺伝子は酵母の $N$ - 結合型糖鎖の ポリマンノース外鎖形成の際の開始に特異的な $\alpha-1,6$-マンノース 転移酵素をコードしていることを見出した。さらに、このポリ マンノース外鎖はOCHI遺伝子を破壊することで取り除けること を示した。

\section{C. 酵母の糖鎖のマンノースリン酸化 (10)}

ポリマンノースから成る糖外鎖はOCHI遺伝子の破壞により 取り除くことが出来たが、マンノースリン酸残基が醰母特異的 糖鎖残基として残っていた(11)。糖鎖のリン酸化は動物細胞でも リソソームへの輸送シグナルとして働くマンノース-6-リン酸と して存在する $(12,13)$ 。しかしながら、酵母の場合、このマン ノース-6-リン酸のリン酸にさらにマンノースが付加しており、 強い抗原性を示す。酵母でのマンノースリン酸残基の付加は、 哺乳類で行われるUDP-GlcNAcからのGlcNAc-1-リン酸転移の代 わりに、GDP-マンノースからのマンノース-1ーリン酸の転移に よっておこる。哺乳類細胞では、この後GlcNAc-1ーリン酸の GlcNAc残基が酵素により切除されるが、酵母ではマンノース-1リン酸のマンノース残基は切除されない。このマンノースリン 酸化は $N$-および $O$ - 結合型糖鎖で起こる $(11,14) 。 N$ - 結合型糖 鎖のERで合成される共通部分 $\left(\mathrm{Man}_{8} \mathrm{GlcNAc}_{2}\right)$ にも、また、マン ノースリン酸残基は結合する。それゆえ、このマンノースリン 酸残基は、酵母でヒト適合型糖タンパク質の生産を行う場合、 取り除かなければならない。

幸運にも、このマンノースリン酸化に関する欠損変異は、 すでにmnn4 (15)およびmnn6 (16)として知られていた。mnn4 お よび mnn6 変異株はアルシアンブルー色素による染色がされない という表現形を示す。MNNG遺伝子はこのアルシアンブルー色素 の染色の相補性を用いて単離された(6)。MNN6 遺伝子は446アミ ノ酸からなるII型膜タンパク質をコードしている。また、Mnn6p はKre2pと相同性の高いタンパク質であるKtr6pと同一であった。 Kre2pは $\alpha-1,2$-マンノース転移酵素であることが知られていたの で、Mnn6pもマンノースリン酸転移酵素そのものであると考えら れた。事実、mnn 6 遺伝子破壊株から調製した膜画分にはマン 
disruptant did not show mannosylphosphate transferase activity, but activity was observed in the membrane fraction of mnn6 disruptant that was transformed with $M N N 6$ gene. We investigated the substrate specificity of Mnn6p using various sugar chains and found that $\alpha-1,2$-linked mannobiose unit was required for recognition as an acceptor. However, no difference of ratio in mannosylphosphorylated $\mathrm{Man}_{8} \mathrm{GlcNAc}_{2}$ was observed between the mnn6 disruptant and MNN6 wild type cells. This may indicate that a different gene encoding a mannosylphosphate transferase exists than the MNN6 gene, and another mannosylphosphate transferase transfers the mannosylphosphate residue to $\mathrm{Man}_{8} \operatorname{GlcNAc}_{2}(6)$.

The $M N N 4$ gene encodes a type II membrane protein consisting of 1178 amino acids with a remarkable tandem repeat of four lysines and four glutamic acids at the $\mathrm{COOH}$-terminus region (5). The MNN4 gene seems to encode a positive regulator of mannosylphosphorylation because mannosylphosphorylation was not recovered by the $M N N 4$ gene over expression in $M N N 6$ gene disrupted cells (17). Although the function of Mnn4p is still not known, the gene disruption of $M N N 4$ showed a lack of mannosylphosphorylation in $\mathrm{N}$ - and $O$-linked oligosaccharides $(5,14)$. Especially, the mannosyphosphate residue transfer to $\mathrm{Man}_{8} \mathrm{GlcNAc}_{2}$ was reduced in the mnn4 gene disruptant (5). This result indicated that $M N N 4$ gene disruption was effective to remove the mannosylphosphate residue from oligosaccharides of glycoproteins.

\section{Molecular Breeding of Yeast that Produces Glycoprotein that Added Mammalian High Mannose Type Oligosaccha- ride}

In conclusion, we had succeeded in cloning the $\mathrm{OCHI}$ gene which encodes initiation specific $\alpha-1,6$-mannosyltransferase for the synthesis of yeast poly-mannose outer chain. The $M N N 4$ and $M N N 6$ genes were also cloned as yeast specific mannosylphosphorylation genes. In particular, in the $M N N 4$ gene disruptant cells, mannosylphosphorylation of almost all oligosaccharides was not observed. Except $\mathrm{OCH1}$ and $M N N 4$ genes, the $M N N 1$ gene has been known as the gene that encodes the yeast specific terminal $\alpha-1,3$-mannosyltransferase (7). The $\mathrm{OCH} 1$ and $\mathrm{MNN} 4$ genes that were isolated by us were disrupted with the MNN1 gene in yeast cells, and we found the most of the $N$-linked oligosaccharide in this triple gene disruptant cell was $\mathrm{Man}_{8} \mathrm{GlcNAc}_{2}$ (Fig. B), which is a kind of mammalian high mannose type oligosaccharide. This result indicates that this triple gene disruptant cell is not attached an oligosaccharide that exhibits an immunogenecity against humans to glycoproteins.

\section{E. Production of $\operatorname{Man}_{5}$ GlcNAc$_{2}$ Type Sugar Chain in \\ S. Cerevisiae}

As described above, we could produce a $\mathrm{Man}_{8} \mathrm{GlcNAc}_{2}$ type sugar chain, which had the same structure as an intermedi-
ノースリン酸転移酵素活性は見出されなかったが、MNN6遺伝子 を導入したmnn6遺伝子破壞株から調製した膜画分では活性は検 出された。Mnn6pの基質特異性について種々の糖鎖を用いて調 ベたところ、 $\alpha-1,2$-結合したマンノース 2 残基のユニットを 糖受容体として必要とすることが分かった。しかしながら、マ ンノースリン酸化された $\mathrm{Man}_{8} \mathrm{GlcNAc}_{2}$ の比率は、mnn6遺伝子破 壊とMNN6遺伝子に関しては野生型株のものとでは違いが見られ なかった。これは、MNNG遺伝子以外にマンノースリン酸転移酵 素をコードする遺伝子が存在し、そのマンノースリン酸転移酵 素がMan $\mathrm{GlcNAc}_{2}$ にマンノースリン酸残基を転移することを示 している(6)。

MNN4遺伝子は、1178アミノ酸残基からなる C -末端領域に 4 残基のリジンと 4 残基のグルタミン酸残基の特徵的な繰り返し 構造を持ったII型膜タンパク質をコードしている(5)。MNN6遺伝 子破壊株でMNN4 遺伝子を過剩発現させてもマンノースリン酸 化は回復しないことから、MNN4遺伝子は正の制御因子をコード していると思われた(17)。MNN4遺伝子の機能は、現在も不明で あるが、MNN4遺伝子の破壞は $N$-および $O$-結合型糖鎖のマン ノースリン酸化の欠損を示す $(5,14)$ 。特に $\mathrm{Man}_{8} \mathrm{GlcNAc}_{2}$ へのマ ンノースリン酸残基の転移はmnn4遺伝子破壊株では減少してい る(5)。このことは、MNN4遺伝子の破壊は糖タンパク質の糖鎖 からマンノースリン酸残基を取り除くのに効果があることを示 している。

\section{D. 動物細胞の高マンノース型糖鎖を持つ糖タンパク質を生産 する酵母の分子育種}

これまで述べてきたように、我々は、酵母のポリマンノー 久糖外鎖合成の最初に必要な $\alpha-1,6$-マンノース転移醭素をコー ドする $O C H I$ 遺伝子の単離に成功した。さらに、この他に酵母特 異的な糖鎖として存在するマンノースリン酸付加に関する遺伝 子として、MNN4とMNN6遺伝子の単離に成功した。特にMNN4 遺伝子の破壊株では糖鎖のマンノースリン酸化がほとんど観察 されなかった。このOCHIとMNN4以外に、MNNI遺伝子が、酵 母特異的な末端の $\alpha-1,3$-マンノース転移酵素をコードしている ことが知られていた(7)。そこで我々は、我々が取得した OCHI およびMNN4遺伝子と、MNN1遺伝子の3つを同時に破壞した株 を作成した。その結果、この3つの遺伝子を破壞した株の糖タン パク質の $N$-結合型糖鎖は、ほぼ全てが動物細胞の高マンノース 型糖鎖の一つである $\mathrm{Man}_{8} \mathrm{GlcNAc}_{2}$ の糖鎖であることが分かった (図B)。この結果、この3つの遺伝子破壞株ではヒトに対する抗 原性を持つ糖鎖はタンパク質に付加しないことを示している。

\section{E. 出芽酵母における $\mathrm{Man}_{5} \mathrm{GlcNAc}_{2}$ 型糖鎖の生産}

前述の通り、 $\Delta o c h 1 \Delta m n n 1 \Delta m n n 4$ の三重破壊株の作製によ り、哺乳類で見られる糖鎖の中間体と同様の構造である 
ate of a mammalian oligosaccharide, in the $S$. cerevisiae $\Delta$ och 1 $\Delta m n n l \Delta m n n 4$ mutant strain. To change the yeast sugar chains into mammalian ones, a number of genes that encode glycosyltransferases, glycosidases, and sugar-nucleotide transporters must be introduced into the mutant cells.

The first step is a conversion of the $\mathrm{Man}_{8} \mathrm{GlcNAc}_{2}$-type to $\mathrm{Man}_{5} \mathrm{GlcNAc}_{2}$-type by mannosidase I. Mannosidase I cuts only the $\alpha-1,2$-mannoside linkage in the $\mathrm{Man}_{8} \mathrm{GlcNAc}_{2}$. Therefore, we have to use $\alpha-1,2$-mannosidase. Several genes encoding $\alpha-1,2$-mannosidase have been isolated from yeast and fungi (18), and some mammalian $\alpha-1,2$-mannosidase genes have also been cloned $(20,21)$. A truncated soluble form of human $\alpha-1,2-$ mannosidase IB was produced as a secreted protein from Pichia pastoris (22). However, the cloning and expression of these genes in yeast had not been achieved when we started our work. The $S$. cerevisiae $\alpha-1,2$-mannosidase gene (MNS1) was one of the well-studied enzymes, and cloning (23) and crystal structural analysis of the Mns1 protein were also performed (47). Substrate specificity of the Mnslp showed that only one $\alpha$-1,2-linked mannose residue in the middle arm of $\mathrm{Man}_{9} \mathrm{GlcNAc}_{2}$ sugar chain was removed (23), indicating that the enzyme was not suitable for conversion of the $\mathrm{Man}_{8} \mathrm{GlcNAc}_{2}$-type to $\mathrm{Man}_{5} \mathrm{GlcNAc}_{2}$-type. Among fungi species, $\alpha-1,2$-mannosidase genes were cloned from Aspergillus saitoi (24) and Penicillium citrinum (19). The A. saitoi $\alpha$-1,2-mannosidase gene ( $m s d S$ ) was introduced into the yeast cells as a chimeric gene with a signal sequence derived from the aspergillopepsin I gene from A. saitoi $(24,25)$, and the fusion protein was successfully expressed. Recombinant $\alpha-1,2-$ mannosidase activity was detected in the culture medium, indicating that the products of the $m s d S$ gene passed through the yeast secretory pathway. Therefore, we thought that this enzyme would be useful to produce the mammalian-type sugar chains in yeast, if it could be retained in the endoplasmic reticulum (ER) or in the lumen side of the Golgi apparatus. After this conversion by $\alpha$-1,2-mannosidase, many enzymes consecutively act on the $\mathrm{Man}_{5} \mathrm{GlcNAc}_{2}$; we decided to make the A. saitoi $\alpha-1,2-$ mannosidase express in the ER.

In $S$. cerevisiae, His-Asp-Glu-Leu (HDEL), the C-terminal sequence of proteins, is known to be involved in a retention mechanism in the ER (26). This sequence is also called the 'ER retention/retrieval signal'. Proteins with an HDEL sequence will be trapped and retrograde transported into the ER by a membrane-bound receptor that is encoded by the ERD2 gene and is localized in the cis-Golgi network (27, 28).

We constructed the chimeric gene by adding 'HDEL' to the C-terminus of the A. saitoi $\alpha-1,2$-mannosidase open reading frame and introduced it into the triple disruptant as described above (48). Expressed $\alpha-1,2$-mannosidase was mainly localized in the ER, and the $\alpha-1,2$-mannosidase activity was detected in the ER fraction prepared by ultracentrifugation (48). We ana-
$\mathrm{Man}_{8} \mathrm{GlcNAc}_{2}$ を酵母で生産することが可能となった。この糖鎖 をさらに哺乳類型に近づけるためには、種々の糖転移酵素、糖 分解酵素、糖又クレオチドトランスポーターなどを酵母内で発 現させていく必要がある。

第一段階はマンノシダーゼIによる $\mathrm{Man}_{5} \mathrm{GlcNAc}_{2}$ への変換で ある。マンノシダーゼIは Man ${ }_{8} \mathrm{GlcNAc}_{2}$ の $\alpha-1,2$-マンノシド結合 を切断する酵素である。したがって、我々の目的のためには $\alpha$ 1,2-マンノシド結合を選択的に切断する酵素（ $\alpha-1,2$-マンノシ ダーゼ）を利用する必要がある。 $\alpha$ ーマンノシダーゼに関わるい くつかの遺伝子が酔母抢よびカビから分離されており(18)、ま た、哺乳動物からも同様に遺伝子がクローニングされてきた(20, 21)。ヒト $\alpha$-マンノシダーゼ IB は可溶型として Pichia pastris で 分泌性タンパク質として発現された報告がある(22)。しかしこれ らは我々が研究を開始した段階ではまだクローニングされてお らず、酵母での発現に成功していなかった。S. cerevisiae の $\alpha$-マ ンノシダーゼ遺伝子 (MNSI) は精力的に研究された酵素の一つ であり、クローニング(23)や結晶構造解析(47)の報告がある。し かし、この酵素はMan $\mathrm{GlcNAc}_{2}$ からマンノースを1残基だけしか 切断できないので(23)、我々の目的には不適であった。カビ由来 のものではAspergillus saitoi(24)やPenicillium citrinum(19)の $\alpha-1$, 2-マンノシダーゼ遺伝子もクローニングされている。A. saitoi由 来の酵素遺伝子 $(m s d S)$ は、A. saitoi から得られたアスペルギロペ プシンI遺伝子のシグナルシーケンスを付加したキメラ遺伝子と して酵母に導入され $(24,25)$ 、培地中に可溶型タンパク質として 発現された。このことは $m s d S$ の融合タンパク質が分泌経路を通 過したことを示している。従って、この酵素を酵母の小胞体 (ER) あるいはゴルジ体のルーメン側に機能的に局在することが できれば、我々の実験に有効である。この反応は第一段階で、 以後多くの糖転移酵素群が逐次的に作用しなければならないの で、我々は小胞体内で発現させることを考えた。

S. cerevisiaeの小胞体局在メカニズムとして知られているの が、タンパク質C末端側のHis-Asp-Glu-Leu (HDEL) の配列であ る(26)。これはER保持／回収シグナルとも呼ばれており、ERGolgi間の小胞内で発現しているERD2遺伝子にコードされる HDEL認識タンパク質によってトラップされ、小胞体へ逆行輸送 されるものと考えられている $(27,28) 。$

A. saitoi の $\alpha-1,2-$-マンノシダーゼのオープンリーディングフ レームの C 末端にHDEL 配列を付加するようなキメラ遺伝子を 作製し、前述の三重破壞株に導入した(48)。発現した $\alpha-1,2-$-マ ノシダーゼは主に小胞体に発現しており、また小胞体画分中に $\alpha-1,2$-マンノシダーゼ活性を確認できた(48)。この組み換え酵母 の細胞内糖タンパク質であるカルボキシペプチダーゼ $\mathrm{Y} 、$ 細胞 壁のマンノプロテインについて糖鎖構造を調べたところ、 $\alpha-1$, 
lyzed the sugar chains of intracellular carboxypeptidase $Y$ and of cell wall mannoproteins from the recombinant disruptant. The structure of the sugar chains from the triple disruptant harboring only the null vector was $\mathrm{Man}_{8} \mathrm{GlcNAc}_{2}$ as expected. Compared with the sugar chains from the disruptant with the null vector, those from the recombinant disruptant contained $\mathrm{Man}_{5} \mathrm{GlNAC}_{2}$, which was the intermediate form for hybrid- and complex-type sugar chains (48). Therefore, we achieved our first aim, to convert the yeast sugar chain into a mammalian one.

\section{F. Trial for the Production of Hybrid- and Complex-Type Sugar Chains in S. cerevisiae}

The next step of $N$-linked oligosaccharide modification was conyersion into the hybrid-type by the addition of GlcNAc residue in the Golgi apparatus. To make this possible, $\mathrm{N}$ acetylglucosaminyltransferase and UDP-GlcNAc transporter as well as a supply of $\mathrm{Man}_{5} \mathrm{GlcNAc}_{2}$ acceptor were needed. We previously reported that rat UDP-N-acetylglucosamine: $\alpha-3$-Dmannoside $\beta-1,2-N$-acerylglucosaminyltransferase I (GnT-I) was successfully expressed in S. cerevisiae (29). Upon expression and careful characterization of GnT-I in S. cerevisiae, it was revealed that the expressed enzyme is localized in various organelles. Subsequently, we introduced one copy of the gene by homologous recombination into the triple disruptant, and most activity was detected in the Golgi fraction. For our purpose, Golgi localization of GnT-I is important because $\alpha-1,2$-mannosidase is localized in the ER, providing $\mathrm{Man}_{5} \mathrm{GlcNAc}_{2}$ as the acceptor for GnT-I.

Given that we could express GnT-I protein in yeast, the UDP-GlcNAc transporter is another requirement. UDP-GlcNAc, which is the donor substrate for GnT-I, is synthesized in the cytosol and must be transported from the cytosol to the lumen of the Golgi apparatus in order to provide a donor substrate for sugar transfer. There are two UDP-GlcNAc transporters that could be selected, one from $S$. cerevisiae, the other from human. In our search for a homologue of the Kluyveromyces lactis $M N N 2$-2 UDP-GlcNAc transporter, we found that the gene YEA4 encodes a protein having $40 \%$ identity and $70 \%$ similarity of amino acid sequences with the Mnn2-2 protein in S. cerevisiae (33). We therefore tested the possibility that its product is a UDPGlcNAc transporter and demonstrated that overproduction of the Yea4 protein increases UDP-GlcNAc transport activity. This transport activity of Yea4 protein is saturable with a high concentration of UDP-GlcNAc and shows the same apparent $K_{m}$ values as those measured for the $K$. lactis Golgi-localized UDPGlcNAc transporter $(30,31)$ and the rat liver ER-localized UDPGlcNAc transporter (32).

There are no GlcNAc residues in the outer chain of the glycoproteins from $S$. cerevisiae. To assess the possible biological role of this UDP-GlcNAc transporter in the ER membranes, we constructed and analyzed a yeast strain deleted for YEA4
2-マンノシダーゼ遺伝子を導入しない株では $\mathrm{Man}_{8} \mathrm{GlcNAc}_{2}$ の構造 を有していたのに対し、遺伝子導入株では一部の糖鎖が $\mathrm{Man}_{5} \mathrm{GlcNAc}_{2}$ の構造に変換されていた(48)。この $\mathrm{Man}_{5} \mathrm{GlcNAc}_{2}$ の 構造は、ヒト混成型および複合型糖鎖の中間体であるので、ヒ ト型糖鎖への変換の第一段階を達成できた。

F. 出芽酵母における混成型および複合型糖鎖の生産を目指して $N$ - 結合型糖鎖修飾の次の段階は、ゴルジ装置内での $N-ア$ セチルグルコサミンの付加反応である。これを行なわせるため には、アクセプターとなる $\mathrm{Man}_{5} \mathrm{GlcNAc}_{2}$ を供給するのはもちろ んのこと、N-アセチルグルコサミン転移酵素とUDP- $N$-アセチル グルコサミントランスポーターを酵母に導入する必要がある。

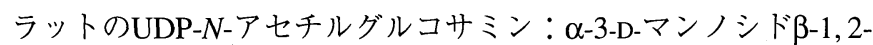
$N$-アセチルグルコサミニルトランスフェラーゼ I (GnT-I)を出芽 酵母において活性を有する形で過剩発現できたことがすでに報 告されている(29)。その酵母株においてGnT-Iの局在を解析した 結果、この酵素は様々な細胞内小器官に分布していた。しかし その後の研究で、遺伝子を1コピーだけ導入した株ではほとんど の活性がゴルジ体画分に存在することが示された。 $\alpha-1,2-$ マン ノシダーゼを小胞体に存在させ、GnT-I のアクセプターとして $\mathrm{Man}_{5} \mathrm{GlcNAc}_{2}$ を供給することができたので、GnT-Iをゴルジ体内 に局在させることは重要なポイントであった。

GnT-Iの発現ができたので、もうひとつ必要なものはUDP$N$-アセチルグルコサミントランスポーターの発現である。GnTIのドナー基質であるUDP- $N$-アセチルグルコサミンは細胞質で合 成されるため、糖転移反応のドナー基質を供給するためには、 UDP- $N$-アセチルグルコサミンが細胞質からゴルジ内腔へ輸送さ れる必要がある。UDP- $N$-アセチルグルコサミントランスポー ターに関しては、2つの選択肢があった。一つは出芽酵母由来の ものであり、もう一つはヒト由来のものである。我々は Kluyveromyces lactisのUDP- $N$-アセチルグルコサミントランス ポーター遺伝子であるMNN2-2遺伝子の出芽酵母のホモログを検 索した結果、アミノ酸レベルの比較でMnn2-2タンパク質と $40 \%$ の同一性、70\%の類似性を示すタンパクをコードしているYEA4 遺伝子を発見した(33)。さらにYEA4遺伝子産物がUDP- $N$-アセチ ルグルコサミントランスポーターである可能性を検討し、YEA4 の過剩発現によりUDP- $N$-アセチルグルコサミン輸送活性が増加 されることを証明した。このトランスポート活性は、過剩の UDP- $N$-アセチルグルコサミンにより 飽和する性質を有し、見か け上の $K_{m}$ 值は $K$. lactisのゴルジ体に存在するUDP- $N$-アセチルグ ルコサミントランスポーター $(30,31)$ や、ラットの肝臓に存在 する小胞体局在性のUDP- $N$-アセチルグルコサミントランスポー ター(32)と同等であった。

出芽酵母の糖タンパク質中の外糖鎖には $N$-アセチルグルコ サミン残基は見いだされない。そこでYEA4にコードされるUDPN-アセチルグルコサミントランスポーターの生物学的な役割を 明らかにするために、我々はYEA4遺伝子を破壊した酵母株を作 
Trends in Glycoscience and Glycotechnology Vol.13 No.72 (July 2001) pp.421-431

(33). Comparatively, the null disruptant cells showed less UDPGlcNAc transport activity to the wild type cells. The disruptant cells showed no apparent differences with the wild type ones in staining with FITC-conjugated concanavalin A. However, staining of the mannan layer of the cell wall with FITC-conjugated wheat germ agglutinin, which is a GlcNAc-specific lectin for yeast, and with Calcofluor white, which is a fluorescence dye that binds to chitin microfibrils, revealed less staining in the disruptant than in the wild type cells. The content of cellular chitin was also reduced in the disruptant compared to that in the wild type cells. These data indicated that the yeast UDP-GlcNAc transporter-encoded YEA4 gene is required for chitin synthesis of the cell wall.

An alternative choice is the UDP-GlcNAc transpoter from human. Based on its similarity to the human UDP-galactose (UDP-Gal) transporter, the human UDP-GlcNAc transporter was identified by a homology search in the expressed sequence tags (EST) database. The human transporter was expressed in S. cerevisiae, and the membrane fractions prepared from the yeast cells showed much higher UDP-GlcNAc transport activity (34). We have also confirmed the human transporter's Golgi localization and topology by using Golgi and ER marker proteins (our unpublished data).

For our purpose, the latter transporter had better potential; the S. cerevisiae Yea4p was localized in the ER, and the human transporter was localized in the Golgi apparatus. In our system, it was considered preferable to supply UDP-GlcNAc in the Golgi apparatus, given that rat GnT-I was mostly localized in the Golgi compartment of yeast.

In order to create a complex-type sugar chain like that observed in mammals, other glycosyltransferases, glycosidases, and sugar-nucleotide transporters must be expressed in $S$. cerevisiae. We have cloned several genes encoding those enzymes and transporters to produce a biantennary complex -type sugar chain, and we have tried to express these genes individually in yeast. The next trial involved the expression of the mannosidase II in the Golgi apparatus of $S$. cerevisiae with an appropriate topology, which would trim the GlcNAcMan $\mathrm{GlcNAc}_{2}$ structure to GlcNAcMan GlcNAc $_{2}$. Human mannosidase II was expressed in the Golgi apparatus of yeast without constructing a fusion protein with the transmembrane region of $\mathrm{OCH} 1$, which is a yeast mannosyltransferase localized in the Golgi apparatus (unpublished data). Simultaneously, we attempted to express the human UDP- $N$-acetylglucosamine: $\alpha$-6-D-mannoside- $\beta$-1, 2- $N$-acetylglucosaminyltransferase II (GnT-II) gene (35) in S. cerevisiae. GnT-II was also expressed in an active form by introducing cDNA coding the GnT-II amino acid sequence, as in the case of mannosidase II (unpublished data).

When we succeed in the addition of GlcNAc, the product can serve as an acceptor for the galactose addition, which is
製し、解析した(33)。この遺伝子破壊株は野生型に比べて低い UDP-N-アセチルグルコサミン輸送活性を示した。この破壊株の 細胞壁について解析したところ、ConAによるマンナン層の染色 には影響が見られなかった。ところが、キチンを認識するコム ギ胚芽レクチン (WGA)やCalcofluor Whiteによる染色は、野生型 に比べて明らかに減少しており、また組成分析でもキチンの含 量が減少していた。このことからYEA4にコードされるUDP- $N$-ア セチルグルコサミントランスポーターは、細胞壁のキチン合成 に関与していると考えられた。

もう一つの選択はヒト由来のUDP- $N$-アセチルグルコサミン トランスポーターである。ヒトのUDP- $N$-アセチルグルコサミン トランスポーターは、ヒトのUDP-ガラクトース (UDP-Gal)トラン スポーターに対する類似性に基づいてEST データベースをホモロ ジー検索することにより同定された。このヒトのトランスポー ターを出芽酵母で発現させ、細胞より回収した膜画分ではUDP$N$-アセチルグルコサミン輸送活性が大幅に増加していた(34)。 我々はこのトランスポーターがゴルジ体に存在することと、膜 への配向性をゴルジ体と小胞体のマーカーを用いることにより 確認した(未発表データ)。

我々の目的にはヒトUDP-N-アセチルグルコサミントランス ポーターの方が適していると考えられる。つまり、出芽酵母の Yea4pは小胞体に局在しているが、ヒト由来のUDP- $N$-アセチルグ ルコサミントランスポーターはゴルジ体に存在するからであ る。酵母内で発現させたラットGnT-Iは大部分がゴルジ体に存在 するため、我々の系では、ゴルジ体にUDP- $N$-アセチルグルコサ ミンを供給する方が良いと考えられる。

さらに哺乳類で見られる複合型糖鎖を作るためには、他の 糖転移酵素、糖分解酵素、糖又クレオチドトランスポーターを 発現させる必要がある。我々は二本鎖複合型糖鎖の生産のため に必要な遺伝子群をそれぞれ単離し、個々の遺伝子を酵母内で 発現させることについても検討してきた。まず、 $\mathrm{GlcNAcMan}_{5} \mathrm{GlcNAc}_{2}$ 構造を GlcNAcMan $\mathrm{GlcNAc}_{2}$ に変換するのに 必要なマンノシダーゼIを発現させることを検討した。ヒトマン ノシダーゼII は、酵母のゴルジ体内タンパク質であるOCH1の膜 貫通領域との融合タンパク質を作らなくても、ゴルジ体内で活 性を有した形で発現した(未発表データ)。同様に我々はヒトの

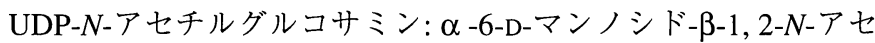
チルグルコサミン転移酵素II (GnT-II) 遺伝子(35)を出芽酵母にお いて発現させることも試みた。ヒトマンノシダーゼ II と同様、 GnT-IIもcDNAをそのまま発現させることで活性を有した酵素が 発現した(未発表デー夕)。

$N$-アセチルグルコサミンを糖鎖に付加することに成功すれ ば、付加された糖鎖をさらにガラクトースを付加するためのア 
similar to the GlcNAc addition, requires the expression of $\beta$ 1,4-galactosyltranferase in the Golgi lumen and a UDP-Gal transporter to provide a substrate for in vivo galactose addition. Mammalian $\beta$-1,4-galactosyltranferase I is one of the most well studied glycosyltransferases. It has been reported that a full length of human $\beta$-1,4-galactosyltranferase or a chimeric gene encoding a catalytic domain of human $\beta$-1,4-galactosyltranferase ligated to a transmembrane domain of yeast $\alpha-1,2$-mannosyltransferase $(M N T 1)$ was introduced into $S$. cerevisiae $(36,37)$. The expressed fusion protein was localized in the Golgi apparatus and showed in vivo activity of human $\beta$-1,4-galactosyltranferase in $S$. cerevisiae (37). We constructed a chimeric gene consisting of the coding region of the yeast $\mathrm{OCH} 1$ transmembrane domain and a catalytic domain of human $\beta$-1,4-galactosyltranferase and got the same results as those obtained with a MNT1 fusion protein.

Regarding the UDP-Gal transporter, we have reported UDP-Gal transport activity in S. cerevisiae and its localization in the Golgi apparatus, but the gene has yet to be identified (38). On the other hand, UDP-Gal transporter genes from human (39) and Schizosaccharomyces pombe have been cloned (40-43). Human UDP-Gal transporter ( $h U G T 2$ ) has been expressed in $S$. cerevisiae in an active form, which has almost the same specific activity and $K_{\mathrm{m}}$ value as those shown in the human microsomal fraction by in vitro transport assay. Therefore, $h U G T 2$ cDNA is not a regulatory protein but encodes the transporter $(44,45)$.

Notably, it has not yet been demonstrated whether expressed foreign sugar nucleotide transporter ( $h U G T 2$ ) is functional in S. cerevisiae. One hypothesis held that appropriate incorporation of UDP-Gal into the Golgi acquired a simultaneous antitransport of UMP. UMP is made from UDP by pyrophosphatase, and UDP is a byproduct of the reaction of sugar transfer. Therefore, glycosyltransferase and acceptor substrate should be co-expressed for functional analysis of hUGT2 in vivo. We have expressed S. pombe $\alpha$-1,2-galactosyltransferase (gma12 ${ }^{+}$) in S. cerevisiae in order to assay for the UDP-Gal transporter. Because the $\alpha$-1,2-galactosyltransferase can use both $N$ - and $O$ linked sugar chains of glycoproteins as substrates (46), there is no need to supply an exogenous acceptor.

Compared with the wild type cells, $50 \%$ of the cells harboring the $g m a 12^{+}$and $h U G T 2$ were stained by $\alpha$-galactosespecific-lectin conjugated FITC (46). This result indicated that hUGT2 is functional in S. cerevisiae, which suggested that it would be useful for our investigation.

The production of a mammalian-type sugar chain in $S$. cerevisiae will be accomplished by the coordinated co-expression of components described in this review. When we have successfully altered the biosynthetic pathway of yeast toward the production of mammalian-type glycan by this approach, our system will offer economic production of glycoproteins and hold great potential for the application of glycoprotein therapeutics.
クセプターとして用いることができる。N-アセチルグルコサミ ン付加反応と同様に、in vivoでガラクトースを付加するために は、 $\beta-1,4-$ ガラクトシルトランスフェラーゼをゴルジの内腔に発 現させ、かつ酵素の基質を輸送するUDP-Galトランスポーター を発現させることが必要である。哺乳類の $\beta-1,4-$ ガラクトシルト ランスフェラーゼIは最もよく研究されているガラクトース転 移酵素のひとつである。ヒトの $\beta-1,4-$ ガラクトシルトランスフェ ラーゼをそのまま(36)、あるいはヒトの $\beta-1,4-$ ガラクトシルトラ ンスフェラーゼ遺伝子の触媒部位のN末端に、酵母 $\alpha-1,2$-マン ノシルトランスフェラーゼ( $(M N T I)$ の膜貫通領域を融合するよう に構築したキメラ遺伝子を出芽酵母に発現させた例(37)が報告さ れている。発現した融合タンパク質はゴルジ体に存在し、ヒト $\beta$-1, 4-ガラクトシルトランスフェラーゼ活性を有することが報 告されている(37)。我々は醅母OCH1の膜貫通領域との融合タン パク質として発現させ、同様の結果を得ている。

UDP-ガラクトーストランスポーターに関しては、出芽酵母 においてUDP-ガラクトース輸送活性が存在すること、およびそ の分子がゴルジ体に存在することを報告している(38)が、その遺 伝子はまだ同定されていない。一方、ヒト(39) と分裂酵母(40-43) ではUDP-ガラクトーストランスポーターの遺伝子がクローニン グされている。ヒトのUDP-ガラクトーストランスポーター (hUGT2)は出芽酵母で活性を有した形で発現させることができ、 in vitroでの輸送活性もヒトの膜画分のものと同等の比活性・ $K_{\mathrm{m}}$ を示していた。つまりhUGT2は調節タンパク質ではなく、トラ ンスポーターをコードしていることが証明されている $(44,45) 。$

ところで、このhUGT2が酵母内(in vivo)でUDP -ガラクトー 又輸送活性を有している証明はされていなかった。実際に糖又 クレオチドトランスポーターが働く際には、糖転移反応後に生 産されるUMPが対向輸送されるものと考えられている。つま り、 in vivoでのhUGT2の機能を見るためには、糖転移酵素とその アクセプター基質が必要なのである。我々はUDP-ガラクトース トランスポーターを解析するためのツールとして、出芽酵母に 分裂酵母由来の $\alpha-1,2$-ガラクトシルトランスフェラーゼ遺伝子 $\left(\right.$ gma $\left.12^{+}\right)$を導入し、発現させた。この酵素は基質として出芽酵 母の $N$-とO-結合型の糖タンパク質を利用できるため(46)、アク セプターを外から供給する必要がない。

遺伝子を導入しない出芽酵母に対し、gma12+とhUGT2を共 発現させた細胞集団の $50 \%$ ほどの細胞壁が、FITCを結合した $\alpha$ -Galを認識するレクチンにより染色された(46)。この結果から、 hUGT2は出芽酵母内でも正常に機能するものと考えられ、我々 の研究で有効なツールになりうることが示唆された。

これまで述べてきたツールを組み合わせて発現させること により、哺乳類型の糖鎖生産が出芽酵母で可能になると考えら れる。この技術が利用可能になった暁には、安価な糖タンパク 質を生産できるようになり、医療への応用が期待される。 


\section{References}

1. Kukuruzinska, M. A., Bergh, M. L., and Jackson, B. J. (1987) Annu. Rev. Biochem. 56, 915-944

2. Kornfeld, R., and Kornfeld, S. (1985) Annu. Rev. Biochem. 54, 631-664

3. Nakayama, K., Nagasu, T., Shimma, Y., Kuromitsu, J., and Jigami, Y. (1992) EMBO J. 11, 2511-2519

4. Nakanishi-Shindo, Y., Nakayama, K., Tanaka, A., Toda, Y., and Jigami, Y. (1993) J. Biol. Chem. 268, 26338-26345

5. Odani, T., Shimma, Y., Tanaka, A., and Jigami, Y. (1996) Glycobiology 6, 805-810

6. Wang, X.-H., Nakayama, K., Shimma, Y., Tanaka, A., and Jigami, Y. (1997) J. Biol. Chem. 272, 18117-18124

7. Yip, C. L., Welch, S. K., Klebl, F., Gilbert, T., Seidel, P., Grant, F. J., O'Hara, P. J., and MacKay, V. L. (1994) Proc. Natl. Acad. Sci. USA 91, 2723-2727

8. Nakayama, K., Nakanishi-Shindo, Y., Tanaka, A., Haga-Toda, Y., and Jigami, Y. (1997) FEBS Lett. 412, 547-550

9. Nagasu, T., Shimma, Y., Nakanishi, Y., Kuromitsu, J., Iwama, K., Nakayama, K., Suzuki, K., and Jigami, Y. (1992) Yeast 8, 535-547

10. Jigami, Y., and Odani, T. (1999) Biochim. Biophys. Acta 1426, 335-345

11. Ballou, C. E. (1990) Methods Enzymol. 185, 440-470

12. Natowitz, M. R., Chi, M.-M. Y., Lowry, O. H., and Sly, W. S. (1979) Proc. Natl. Acad. Sci. USA 76, 4322-4326

13. Kornfeld, S. (1992) Annu. Rev. Biochem. 61, 307-330

14. Nakayama, K., Feng, Y., Tanaka, A., and Jigami, Y. (1998) Biochim. Biophys. Acta 1425, 255-262

15. Ballou, C. E., Kern, K. A., and Raschke, W. C. (1973) J. Biol. Chem. 248, 4667-4673

16. Karson, E. M., and Ballou, C. E. (1978) J. Biol. Chem. 253, 6484-6492

17. Odani, T., Shimma, Y., Wang, X.-H., and Jigami, Y. (1997) FEBS Lett. 420, 186-190

18. Moremen K.W., Trimble, R.B., and Herscovics, A. (1994) Glycobiology 4, 113-125

19. Yoshida, T., and Ichshima, E. (1995) Biochim. Biophys. Acta 1263, 159-162

20. Herscovics, A., Schneikert, J., Athanassiadis, A., and Moremen, K.W. (1994) J. Biol. Chem. 269, 9864-9871

21. Lal, A., Schutzbach, J. S., Forsee, W. T. Neame, P. J., and Moremen, K.W. (1994) J. Biol. Chem. 269, 9872-9881

22. Tremblay, L. O., Campbell Dyke, N., and Herscovics, A. (1998) Glycobiology 6, 585-595

23. Camirand, A., Heysen, A., Grondin, B., and Herscovics, A. (1991) J. Biol. Chem. 266, 15120-15127

24. Inoue, T., Yoshida, T., and Ichishima, E. (1995) Biochim. Biophys. Acta 1253, 141-145

25. Fujita, A., Yoshida, T., and Ichishima, E (1997) Biochem. Biophys. Res. Commun. 238, 779-783

26. Pelham, H.R. (1988) EMBO J. 7, 913-918

27. Lewis, M.J., and Pelham, H.R. (1990) Nature 348, 162-163

28. Semenza, J. C., Hardwick, K. G., Dean N., and Pelham, H. R. (1990) Cell 61, 1349-1357

29. Yoshida, S., Suzuki, M., Yamano, S., Takeuchi, M., Ikenaga, H., Kioka, N., Sakai, H., and Komano T. (1999) Glycobiology 9, 53-58

30. Abeijon, C., Robbins, P. W., and Hirschberg, C. B. (1996) Proc. Natl. Acad. Sci. USA. 93, 5963-5968

31. Abeijon C., Mandon, E.C., Robbins, P.W., and Hirschberg, C.B. (1996) J. Biol. Chem. 271, 8851-8854

32. Bossuyt X., and Blanckaert , N. (1994) Eur. J. Biochem. 223, 981-988

33. Roy, S. K., Chiba, Y., Takeuchi, M., and Jigami, Y. (2000) J. Biol. Chem. 275, 13580-13587

34. Ishida, N., Yoshioka, S., Chiba, Y., Takeuchi, M., and Kawakita, M. (1999) J. Biochem. 126, 68-77

35. Tan, J., D’Agostro, A. F., Bendiak, B., Reck, F., Sarker, M., Squire, J. A., Leong, P., and Schachter , H. (1995) Eur. J. Biochem. 231, 317-328

36. Krezdorn, C. H., Watzele, G., Kleene, R. B., Ivanor, S. X., and Berger, E. G. (1993) Eur. J. Biochem. 212, 113-120

37. Schwientek, T., Narimatsu, H., and Ernst, J. (1996) J. Biol. Chem. 271, 3398-3405

38. Roy, S. K., Yoko-o, T., Ikenaga, H., and Jigami, Y. (1998) J. Biol. Chem. 273, 2583-2590

39. Yoko-o, T., Roy, S. K., and Jigami, Y. (1998) Eur. J. Biochem. 257, 630-637.

40. Ishida, N., Miura, N., Yoshioka, S., and Kawakita, M. (1996) J. Biochem. 120, 1074-1078

41. Miura, N., Ishida, N., Hoshino, M, Yamauchi, M., Hara, T., Ayusawa, D., and Kawakita, M. (1996) J. Biochem. 120, 236-241

42. Tabuchi, M., Tanaka, N., Iwahara, S., and Takegawa, K. (1997) Biochem. Biophys. Res. Commun. 232, 121-125

43. Yoshioka, S., Sun-Wada, G. H., Ishida, N., and Kawakita, M. (1997) J. Biochem. 122, 691-695

44. Berninsone P., Eckhardt; M., Gerardy-Schahn, R., and Hirschberg, C. B. (1997) J. Biol. Chem. 272, 12616-12619

45. Sun-Wada, G. H., Yoshioka, S., Ishida, N., and Kawakita, M. (1998) J. Biochem. 123, 912-917

46. Kainuma, M., Ishida, N., Yoko-o, T., Yoshioka, S., Takeuchi, M., Kawakita, M., and Jigami, Y. (1999) Glycobiology 9, 133-141

47. Dole, K., Liperi, F., Herscovics, A., and Howell, P. L. (1997) J. Struct. Biol. 120, 69-72

48. Chiba, Y., Suzuki, M., Yoshida, S., Yoshida, A., Ikenaga, H., Takeuchi, M., Jigami, Y., and Ichishima, E. (1998) J. Biol. Chem., 273, 2629826304

Received on April 24, 2001, accepted on June 14, 2001 


\section{Profile of the Authors}

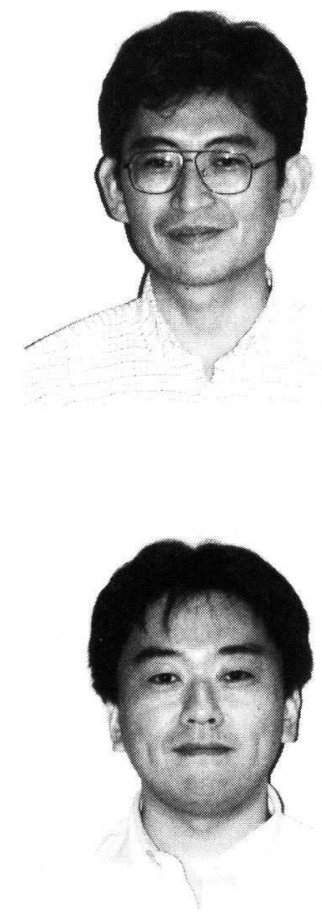

Ken-ichi Nakayama graduated from the Hokkaido University in 1985 and obtained his Ph.D. in Applied Biochemistry from the University of Tsukuba in 1999. He worked as a researcher at the National Chemical Laboratory for Industry (NCLI) and National Institute of Bioscience and Human Technology (NIBH) from 1987 to 1994, and as a senior researcher at NIBH and Institute of Molecular and Cell Biology (IMCB) at the National Institute of Advanced Industrial Science and Technology (AIST) from 1995 to present. He has been studying the glycosyltransferase and sugar structure in yeast.

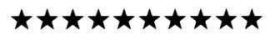

Yasunori Chiba graduated Tohoku University in 1989 and received $\mathrm{Ph} . \mathrm{D}$ in 1994 from the Faculty of Agriculture, Tohoku University. He worked as a JSPS fellow at the Laboratory of Molecular Enzymology, Tohoku University from 1994 to 1996, as a postdoctoral fellow at the Glycotechnology Group of Central Laboratory for Key Technology, KIRIN Brewery from 1996 to 1999, as a NEDO fellow at National Institute of Bioscience and Humantechnology (NIBH) from 1999 to 2001. Since 2001 he has been a research scientist at National Institute of Advanced Industrial Science and Technology (AIST). He has been trying the establishment of mammalian glycosylation system in yeast to produce therapeutic glycoproteins.

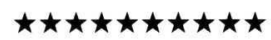

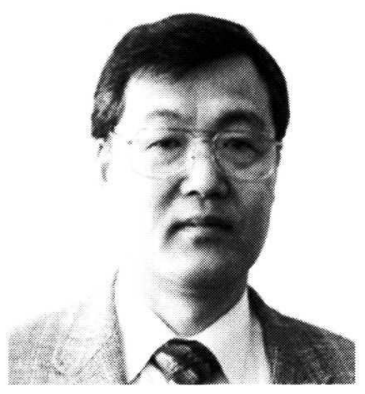

Dr. Yoshifumi Jigami graduated from the University of Tokyo in 1970 and obtained his Ph.D. in Applied Microbiology from the University of Tokyo in 1975.

He worked as a Researcher at the National Chemical Laboratory for Industry (NCLI) from 1976 to 1986, as a Head of Gene Engineering Laboratory at the NCLI and at the National Institute of Bioscience and Human Technology (NIBH) from 1986 to 1995, as a Director of Molecular Biology Department at the NIBH from 1995 to 1996 , as a chief senior researcher at the NIBH from 1996 to 1999 , as a deputy director-general at the NIBH from 1999 to 2001, and as a director of Institute of Molecular and Cell Biology (IMCB) at the National Institute of Advanced Industrial Science and Technology (AIST) from 2001 to present. He is also a Professor of Graduate School of Life and Environmental Sciences at the University of Tsukuba from 1991 to present.

His major research interest is the analysis of yeast cell wall biosynthesis to elucidate the function of carbohydrates attached to cell surface glycoproteins and its application for industry to establish a sugar chain remodeling technology for the production of human compatible therapeutic glycoproteins by yeast. 